\title{
GRI COMPLIANCE AND PREREQUISITES OF INTEGRATED REPORTING FOR ASIAN-PACIFIC COMPANIES
}

\author{
Ioana - Maria Dragu, ${ }^{1}$ \\ Adriana Tiron - Tudor ${ }^{2}$
}

ABSTRACT: Corporate reporting in recent times faces a series of challenges as companies are expected to reassess their strategy for information disclosure. Within a global economic environment that is continuously evolving, there is a strong need for an internationally coordinated action as the financial and non-financial information disclosed by a company influences its strategic decisions. The topic of the current paper outlines the issue of integrated reporting as the interconnection between financial, social and environmental information. We intend to investigate the influence of financial performance on social and environmental disclosure and measure the integration level of corporations that claim to publish integrated reports. The main stages of the research involve the determination of financial ratios and disclosure index levels for environmental and social information. For the purpose of establishing the disclosure index we consider the referential of GRI G3 international standards, while compliance with the standard would be the prerequisite for integrated reports, by contributing to an increase in non-financial disclosure, in addition to the mandatory financial one. Our sample comprises 16 Asian-Pacific companies that participate in the pilot program initiated by the International Integrated Reporting Committee according to which organizations are encouraged to integrate their non-financial information social and environmental disclosure - within annual reports, along with financial data. The research methodology assumes computation of a disclosure index for social and environmental information, and determination of financial ratios for establishing the influence of financial performance on socio-environmental disclosure and the actual level of integration in specific integrated reports. Our findings suggest the financial ratios can be directly, indirectly, and noncorrelated with non-financial information, while the integration process is attained at high, medium, or low levels, according to the aggregation of financial, social, and environmental information.

Keywords: integrated reporting, GRI compliance, social, environmental, and financial information, disclosure index.

JEL Codes: $M 40$

\section{Introduction}

In 2011 the International Integrated Reporting Committee was submitting its first document on integrated reports. Since then, the organization has been the main driver for integrated reporting practices. The IIRC has initiated a pilot program for corporations willing to adopt integrated reporting. This initiative has gained the interest of more than 70 worldwide organizations that decided to submit for this program. For the purpose of our current investigation, we focus only on that particular companies headquartered in Asian-Pacific countries. Our choice is based upon the fact that the evolution of integrated reports could be better monitored if dissipated between regions.

In the absence of a current framework for integrated reporting, we decided to conduct our analysis from the perspective of voluntary disclosure of GRI G3 Guidelines. We check the level of social and environmental information disclosure by identifying the corresponding performance

\footnotetext{
${ }^{1}$ Babes- Bolyai University, Cluj- Napoca, Romania, e-mail: ioanadragu@yahoo.com

${ }^{2}$ Babes- Bolyai University, Cluj- Napoca, Romania
} 
indicators. The financial information is represented by ROE and ROA ratios. The data for our analysis was extracted from 2011 annual integrated reports.

The originality of the current research paper relies in developing the topic of integrated reporting in its earliest stage, at a time when there is no standardized framework for such type of reports. GRI compliance can contribute to integrating financial, social and environmental information within one single, integrated report, as it mentions the most relevant social and environmental elements that can be attributed to a report by voluntary action. The socioenvironmental information adds value to the financial, mandatory information. This study conveys an image upon how corporations manage to integrate their financial and non-financial elements within the annual report and explains whether financial performance has an effect on the level social and environmental disclosure in an annual integrated report.

\section{Review of Literature}

Nowadays, integrated reporting is highly debated on an international scale. Worldwide organizations, institutions, associations, accountancy profession representatives and experts in the field of accounting, along with practitioners, are joining their effort to develop a common global framework. The corporate environment is committed to the cause of integrated reporting, as the pilot program launched by the IIRC has been very successful so far, gaining new members as time passes. The organizations implied in this program are meant to contribute to setting a framework for integrated reports. Therefore, we can resume that the global standards on integrated reporting would evolve from corporate reporting practice. In our particular case, corporate reporting practice will define the actual framework for integrated reports and will conduct to a global set of standards. However, currently the GRI G3 Guidelines represent an important initiative for non-financial reporting.

In year 2000, the Global Reporting Initiative was developing its first version of GRI G3 Sustainability Reporting Guidelines. Later on, they revised the guidelines and re-issued an updated version of the standards. The next step will be to introduce the G4 Guidelines that could mean progress for integrated reports.

The interdependence between financial information disclosure and sustainability information disclosure is strongly debated within the international literature. Katelijne Van Wensen et. al. (2011) considers that sustainability reports tend to become integrated reports. The final stage of integration consists in incorporating financial aspects to complete the non-financial information. The need for integrated reporting emerges on the background of GRI guidelines for sustainability reporting (Benoit \& Niederman, 2010) and financial, social and environmental elements should be unified to generate the single integrated report. Other studies (Uwuigbe et al., 2011) reveal the correlation between financial performance and sustainability and analyse the level of environmental disclosure in connection to performance (Hossain et. al, 2006). Sustainability reporting expectations (Godschalk, 2011) and the positive evolutions of sustainability disclosure and practice (Michael, 2009; Kolk, 2002) underline the importance of sustainability for corporate reporting. Michael (2009) identifies a series of elements for a list of Australian organizations, such as environmental and social issues, headquarter, profile, and other connected criteria. In the same time, Australia becomes one of the first states in which non-for profit organizations adopt integrated reporting (Adams \& Simnett, 2011).

Both financial and non-financial information disclosure represent an area of interest for academics and scholars. Htaybat (2010) studied online reporting practices by determining the unweight disclosure index for 272 organizations. The findings show that most of the sample companies incorporate online reporting. Other studies (Michelon, 2007; Clarkson et. al., 2007; Tsalavoutas, 2009) discuss the implication of environmental performance indicators by modeling the relationship between performance and disclosure of environmental information. The current 
research employs a similar approach, by establishing correlation between social-environmental information disclosure and financial indicators.

Attempts to investigate the corporate social responsibility within Greek banks (Engelinos et. al, 2010) assume deep analysis upon the social and environmental disclosure in annual reports. The methodology involves, among others, GRI guideline scoring. Clausen et al. (2001) mentions possible methods of examining social and environmental disclosure.

Kim (2002) provides a synthesis of the main methods used in sustainability research, namely: analysis of sustainability or environmental reports for the purpose of identification of socio-environmental information; studying the ethical and ecological aspects; usage of sustainability indicators.

Our study incorporates the first and latter categories of methods, by determining the degree of disclosure for environmental and social information, testing the correlation with the financial ratios, and identifying the integration degrees.

\section{Research Methodology}

We selected our sample companies from the IIRC pilot program. All the organizations are headquartered in the Asia-Pacific region and are listed in the table below:

\section{Sample of Prerequisites Integrated reports}

\begin{tabular}{|c|c|c|c|c|c|c|}
\hline $\begin{array}{l}\text { Crt. } \\
\text { No. }\end{array}$ & Organization & Country & Sector & Website & Year & $\begin{array}{l}\text { Report } \\
\text { denomination }\end{array}$ \\
\hline 1 & Mecu Limited & Australia & Banks & www.bankmecu.com.au & 2011 & Annual Report \\
\hline 2 & $\begin{array}{l}\text { National Australia } \\
\text { Bank Limited }\end{array}$ & Australia & Banks & www.nab.com.au & 2011 & Annual Review \\
\hline 3 & Stockland & Australia & $\begin{array}{l}\text { Real estate } \\
\text { investment \& } \\
\text { services } \\
\end{array}$ & www.stockland.com.au & 2011 & $\begin{array}{l}\text { Corporate } \\
\text { responsibility \& } \\
\text { Sustainability } \\
\end{array}$ \\
\hline 4 & Vancity & Canada & Banks & www.vancity.com & 2011 & Annual Report \\
\hline 5 & MASISA S.A. & Chile & $\begin{array}{l}\text { Forestry, wood } \\
\text { and boards }\end{array}$ & www.masisa.com & 2011 & $\begin{array}{l}\text { Integrated } \\
\text { Report }\end{array}$ \\
\hline 6 & $\begin{array}{l}\text { CLP Holdings } \\
\text { Limited }\end{array}$ & China & Electricity & www.clpgroup.com & 2011 & $\begin{array}{l}\text { Sustainability } \\
\text { Report }\end{array}$ \\
\hline 7 & Tata Steel & India & Steel producers & www.tatasteel.com/ & 2011 & Annual Report \\
\hline 9 & $\begin{array}{l}\text { Showa Denki Co. } \\
\text { Ltd. }\end{array}$ & Japan & $\begin{array}{l}\text { Household } \\
\text { goods \& home } \\
\text { construction }\end{array}$ & www.showadenki.co & 2011 & Annual Report \\
\hline 10 & $\begin{array}{l}\text { Takeda } \\
\text { Pharmaceutical } \\
\text { Company Limited }\end{array}$ & Japan & $\begin{array}{l}\text { Pharmaceutical } \\
\text { s \& } \\
\text { biotechnology }\end{array}$ & www.takeda.com/ & 2011 & Annual Report \\
\hline 11 & $\begin{array}{l}\text { Diesel \& Motor } \\
\text { Engineering PLC }\end{array}$ & $\begin{array}{l}\text { Sri } \\
\text { Lanka }\end{array}$ & $\begin{array}{l}\text { Industrial } \\
\text { engineering }\end{array}$ & www.dimolanka.com/ & 2011 & Annual Report \\
\hline 12 & $\begin{array}{l}\text { Cliffs Natural } \\
\text { Resources }\end{array}$ & USA & $\begin{array}{l}\text { Industrial } \\
\text { mining \& } \\
\text { metals }\end{array}$ & $\underline{\text { www.cliffsnaturalresources.co }}$ & 2011 & Annual Report \\
\hline 13 & $\begin{array}{l}\text { Microsoft } \\
\text { Corporation }\end{array}$ & USA & $\begin{array}{l}\text { Software \& } \\
\text { computer } \\
\text { services }\end{array}$ & www.microsoft.com & 2011 & Annual Report \\
\hline 14 & $\begin{array}{l}\text { Prudential } \\
\text { Financial, Inc. }\end{array}$ & USA & $\begin{array}{l}\text { Financial } \\
\text { services }\end{array}$ & www.prudential.com & 2011 & Annual Report \\
\hline 15 & $\begin{array}{l}\text { The Clorox } \\
\text { Company }\end{array}$ & USA & Chemicals & www.thecloroxcompany.com & 2011 & Annual Report \\
\hline 16 & $\begin{array}{l}\text { The Coca-Cola } \\
\text { Company }\end{array}$ & USA & Beverages & $\begin{array}{l}\text { www.thecoca- } \\
\text { colacompany.com }\end{array}$ & 2011 & Annual Review \\
\hline
\end{tabular}

(Source: author's contribution) 
Initially, we had a sample of 18 companies. We had to exclude one of the organizations because the most recent published annual report was the one for year 2010 and it would not have been relevant to compare the information from 2010 reporting period with the one disclosed for year 2011.

In order to test the compliance with GRI G3, we identified the social and environmental performance indicators disclosed within the reports. In addition, for each of the sample company, we examined the financial ratios, ROE, and ROA, testing their correlation with the non-financial information- social and environmental. Regarding the scores for environmental and social information, we used the following codification: " 0 " for the performance indicators that are not mentioned within the report, "0,5" for partial reporting and " 1 " for full disclosure. Further on, we extracted the financial elements of total assets, equity and net income, necessary for determining the ratios of return on equity and return on asset- that represent the financial information.

The disclosure index for social and environmental data has been computed according to the formula stated below:

$$
D I_{I R}=\sum\left(d_{i} \text { effectively disclosed }\right) / \sum\left(d_{i} \text { all possible cases of disclosure }\right)
$$

Our main research question is: Does financial performance influence the integration level in an annual report? As mentioned before, by financial performance we understand the levels of ROA and ROE. We define the integration level as organizations' willingness to disclose more socioenvironmental information. In addition, we develop three hypotheses:

H01: The financial performance will not generate any change in the disclosure of social and environmental information in an IAR.

H02: The financial performance of a company is directly correlated with the disclosure of social and environmental information in an IAR.

H03: The financial performance of a company is indirectly correlated with the disclosure of social and environmental information in an IAR.

\section{Findings}

By extracted the data from the Integrated Annual Report we can observe the connections between the financial information and the non-financial one (Table 2).

Table no. 2 .

Financial, Social and Environmental Information presented in Annual integrated Reports

\begin{tabular}{|c|c|c|c|c|}
\hline Companies & ROA & ROE & Social DI & Environmental DI \\
\hline Mecu Limited & 0,0100 & 0,1000 & 0,0313 & 0,0167 \\
\hline National Australia Bank Limited & 0,0100 & 0,1200 & 0,8646 & 1,0000 \\
\hline Stockland & 0,0500 & 0,0900 & 0,7500 & 0,4833 \\
\hline Vancity & 0,0100 & 0,1100 & 0,5833 & 0,3667 \\
\hline Masisa & 0,0100 & 0,0300 & 0,3542 & 0,8000 \\
\hline CLP Holdings & 0,0400 & 0,1150 & 0,0833 & 0,3333 \\
\hline Tata Steel & 0,1100 & 0,1900 & 0,0417 & 0,1333 \\
\hline Showa Denki & 0,0180 & 0,0690 & 0,6531 & 0,3257 \\
\hline Takeda Pharmaceutical & 0,0900 & 0,1200 & 0,1354 & 0,0667 \\
\hline Diesel \& Motor Engineering & 0,1000 & 0,2700 & 0,9792 & 0,9667 \\
\hline Cliffs Natural Resources & 0,1200 & 0,3100 & 0,0313 & 0,2333 \\
\hline Microsoft Corporation & 0,2100 & 0,4100 & 0,5000 & 0,9667 \\
\hline Prudential Financial & 0,0100 & 0,1000 & 0,0833 & 0,0000 \\
\hline Clorox & 0,1300 & $-1,9651$ & 0,5104 & 0,4500 \\
\hline Coca-Cola & 0,1100 & 0,2700 & 0,1458 & 0,2667 \\
\hline
\end{tabular}

(Source: author's own computations) 
Chart no. 1 shows the evolution of the financial indicators - ROA and ROE-, as well as the social and environmental disclosure index. We can observe that corporations tend to present more environmental than social information in their integrated reports. Regarding the influence of financial ratios on social and environmental disclosure, we can track both direct and indirect correlations. However, ROE seems to generate a higher influence than ROA. We distinguish the case of Clorox Company, with a negative return on equity that registers low socio- environmental disclosures. On the other hand, we found that Mercu Limited has the highest ROE, but low values for social and environmental DI. In other situations, both environmental and social information disclosure have high scores, but ROE and ROA are not significant (National Australia Bank Ltd., Stockland, Vancity, Masisa). Finally there are cases when higher financial performance implies more social disclosure (Prudential Financials), and environmental disclosures (Coca-Cola, Microsoft Corporation, Cliffs Natural Resources, Diesel \& Motor Engineering).

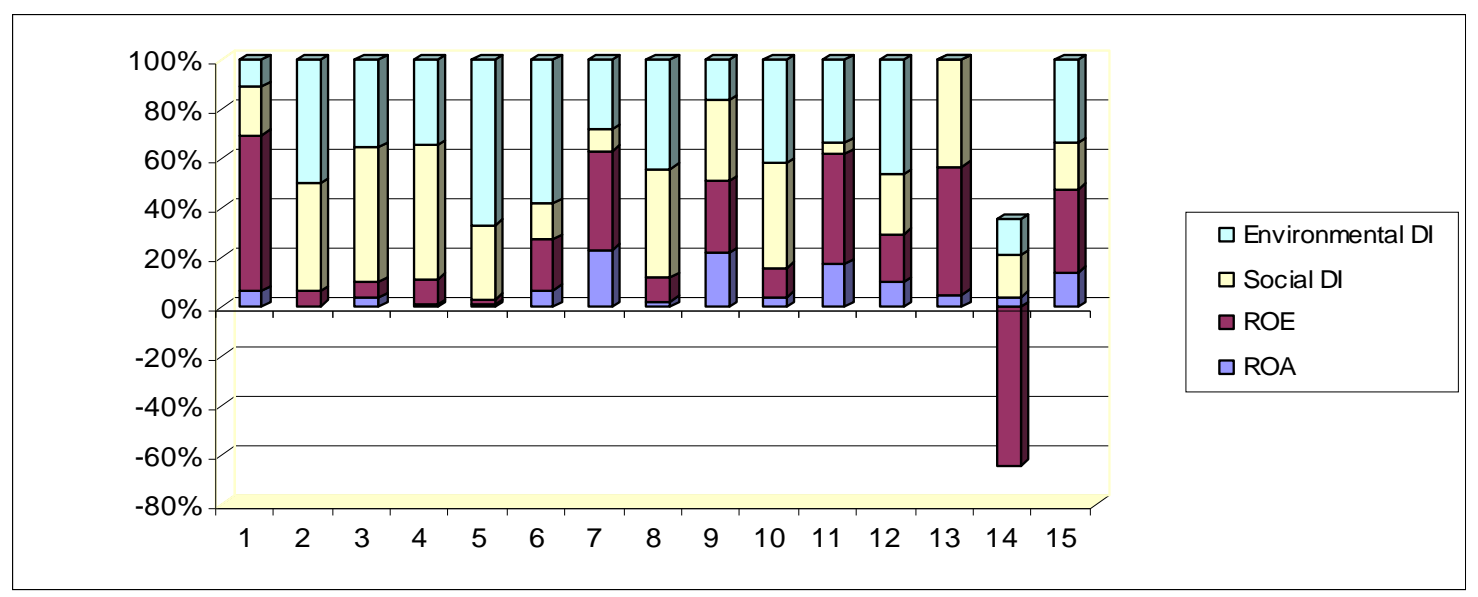

Chart no. 1. - Financial ratios and DI for social and environmental information

(Source: authors' projection)

We should distinguish between the financial information, that is mandatory by legal requirements, and the voluntary non-financial (social and environmental) information that follow a set of guidelines. We consider that the most relevant measurements for the financial information represent the ratios of ROE and ROA. The annual reports of our sample companies disclosed the elements needed for determining these ratios (Net Income, Total Assets, Equity - that are comprised on the balance Sheet and Profit and Loss Statement).

The social and environmental information has been measured using a disclosure index applied to the elements requested by GRI 3 guidelines. Therefore, we tested the GRI compliance on our sample companies.

By definition, integrated reporting means bringing together financial and non-financial (social and environmental) information into one single report. In addition, the integration level has been tested using the following framework: 


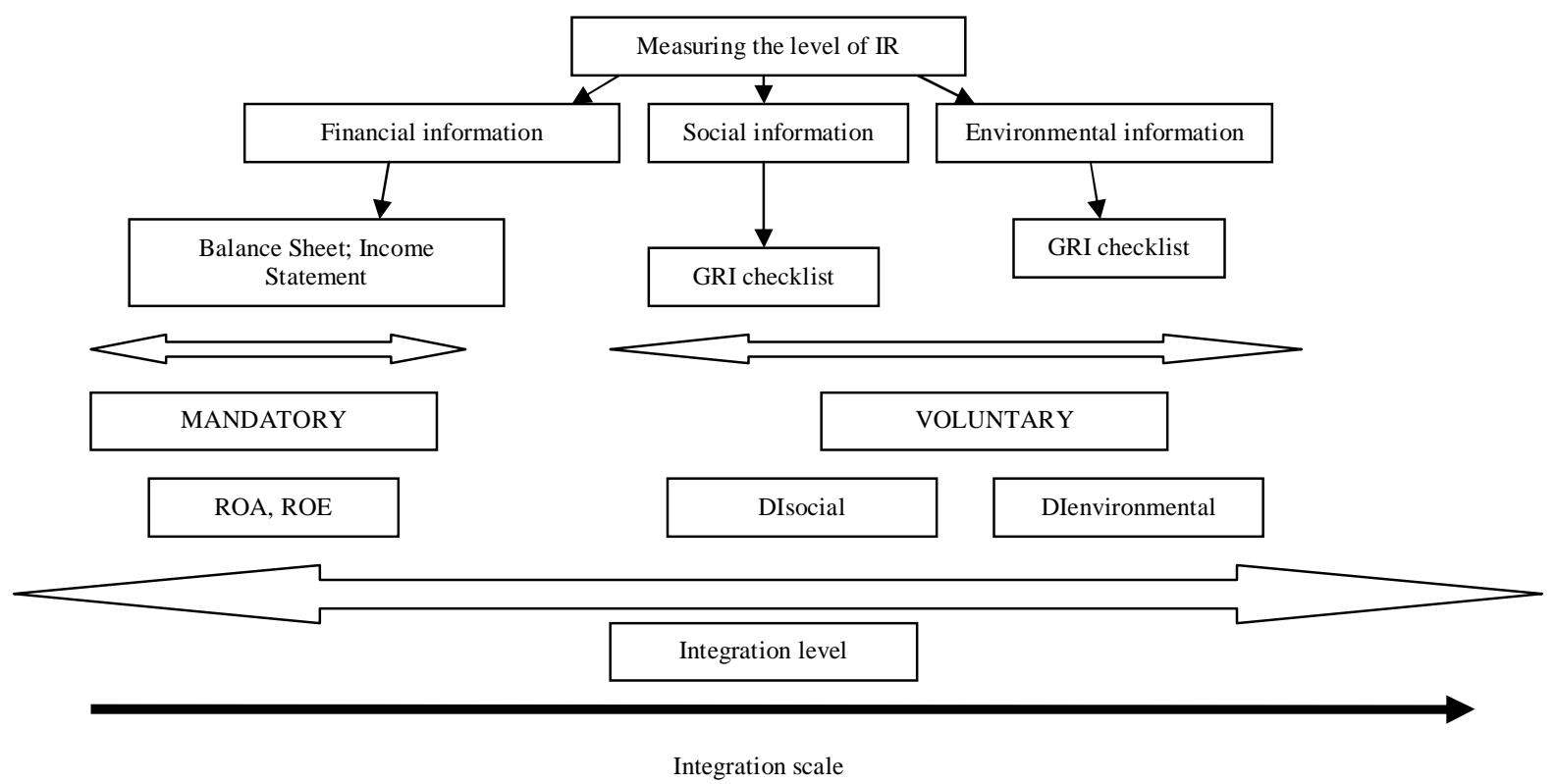

Figure no. 1. - Framework for testing the integration level in the IAR:

The current research perceives the process of integration as an aggregation of information financial, social, and environmental. In addition, we do not claim to study the connection between these elements, as the IIRC is still working on a final document for an IR framework that should show the linkage/interconnection between financial and non-financial information and performance. Regarding social-environmental performance, GRI has joined efforts with the IIRC to develop some specific KPIs that would eventually connect also the financial performance. Actually, our vision on integrated reporting represents a combination of 3 reports into one single document: Financial Report, CSR Report, and Environmental Report. As financial information is mandatory, and organizations have to provide it in the Annual Report, we consider that integration takes place by adding the non-financial (social and environmental) information in the AR. In addition, we try to test if financial performance can influence the integration level on an IAR - that represents the addition of social and environmental disclosure to the financial one according to definition.

Table no. 3 presents the correlations between the financial and non- financial information. For each of our variables (financial - ROE, ROA; and non- financial - environmental DI and social DI) we determine an average value. This value stands as reference in the first part of our analysis for testing the connection between financial ratios and the disclosure level of non-financial information. The same average value is considered in the second part of the analysis, where we investigate the integration of financial with social and environmental information. 
Table no. 3 .

Correlations between financial and non- financial information

\begin{tabular}{|c|c|c|c|c|c|c|c|c|c|c|}
\hline Companies & ROA & & ROE & & Social DI & Check & $\begin{array}{c}\text { Environmental } \\
\text { DI }\end{array}$ & check & TEST & Result \\
\hline Mecu Limited & 0,0100 & below average & 0,1000 & above average & 0,0313 & below average & 0,0167 & below average & $\mathrm{H} 01$ & no correlation \\
\hline $\begin{array}{c}\text { National Australia Bank } \\
\text { Limited }\end{array}$ & 0,0100 & below average & 0,1200 & above average & 0,8646 & above average & 1,0000 & above average & $\mathrm{H} 01$ & no correlation \\
\hline Stockland & 0,0500 & below average & 0,0900 & above average & 0,7500 & above average & 0,4833 & above average & $\mathrm{H} 01$ & no correlation \\
\hline Vancity & 0,0100 & below average & 0,1100 & above average & 0,5833 & above average & 0,3667 & below average & $\mathrm{H} 01$ & no correlation \\
\hline MASISA & 0,0100 & below average & 0,0300 & below average & 0,3542 & below average & 0,8000 & above average & $\mathrm{H} 01$ & no correlation \\
\hline CLP Holdings & 0,0400 & below average & 0,1150 & above average & 0,0833 & below average & 0,3333 & below average & $\mathrm{H} 01$ & no correlation \\
\hline Tata Steel & 0,1100 & above average & 0,1900 & above average & 0,0417 & below average & 0,1333 & below average & $\mathrm{H} 03$ & $\begin{array}{c}\text { indirect } \\
\text { correlation }\end{array}$ \\
\hline Showa Denki & 0,0180 & below average & 0,0690 & above average & 0,6531 & above average & 0,3257 & below average & $\mathrm{H} 01$ & no correlation \\
\hline Takeda Pharmaceutical & 0,0900 & above average & 0,1200 & above average & 0,1354 & below average & 0,0667 & below average & $\mathrm{H} 03$ & $\begin{array}{c}\text { indirect } \\
\text { correlation } \\
\end{array}$ \\
\hline $\begin{array}{c}\text { Diesel \& Motor } \\
\text { Engineering }\end{array}$ & 0,1000 & above average & 0,2700 & above average & 0,9792 & above average & 0,9667 & above average & $\mathrm{H} 02$ & $\begin{array}{c}\text { Direct } \\
\text { correlation }\end{array}$ \\
\hline Cliffs Natural Resources & 0,1200 & above average & 0,3100 & above average & 0,0313 & below average & 0,2333 & below average & $\mathrm{HO3}$ & $\begin{array}{c}\text { indirect } \\
\text { correlation }\end{array}$ \\
\hline Microsoft Corporation & 0,2100 & above average & 0,4100 & above average & 0,5000 & above average & 0,9667 & above average & $\mathrm{H} 02$ & $\begin{array}{c}\text { Direct } \\
\text { correlation } \\
\end{array}$ \\
\hline Prudential Financial & 0,0100 & below average & 0,1000 & above average & 0,0833 & below average & 0,0000 & below average & $\mathrm{H} 01$ & no correlation \\
\hline Clorox & 0,1300 & above average & $\begin{array}{c}- \\
1,9651 \\
\end{array}$ & below average & 0,5104 & above average & 0,4500 & above average & $\mathrm{H} 01$ & no correlation \\
\hline Coca-Cola & 0,1100 & above average & 0,2700 & above average & 0,1458 & below average & 0,2667 & below average & $\mathrm{H} 03$ & $\begin{array}{c}\text { indirect } \\
\text { correlation }\end{array}$ \\
\hline Average & 0,0685 & & 0,0226 & & 0,3831 & & 0,4273 & & & \\
\hline
\end{tabular}

(Source: authors' compilation) 
Our observations indicate that we can distinguish between 3 types of correlations:

- direct correlation (H01)

- indirect correlation (H02)

- no correlation (H03)

The condition of direct correlation was met when both ROA and ROE were above average/below average, and this fact generated a disclosure index that was also above the average/below average. The indirect relationship appeared when having contracts between financial ratios and non-financial information disclosure - either below average ROE and ROA with above average DI for social and environmental information, or the other way around - meaning that an increase in the financial performance leads to a decrease in nonfinancial disclosure. Direct correlation applies only for two out of our 16 sample companies: Diesel \& Motor Engineering and Microsoft Corporation. More than that, the results show only that an eventual decrease in financial ratios generates low socio- environmental disclosure rates. A possible explanation could be that a decrease in financial performance might cause corporation become less interested in social and environmental accountability. Five companies from the sample maintain an indirect correlation in which low rates for ROE and ROA conduct to high disclosure in social and environmental data: Tata Steel, Takeda Pharmaceutical, Cliffs Natural Resources, Coca-Cola. Here the explanation can be found in the marketing strategy for organizations to gain credit from customers, creditors, community, and other stakeholders. All the other companies present no correlation between their financial scores and non-financial information disclosure

The second part of the analysis considers the integration level of the annual reports. We discuss the integration of financial and non- financial information starting from the three types of correlations:

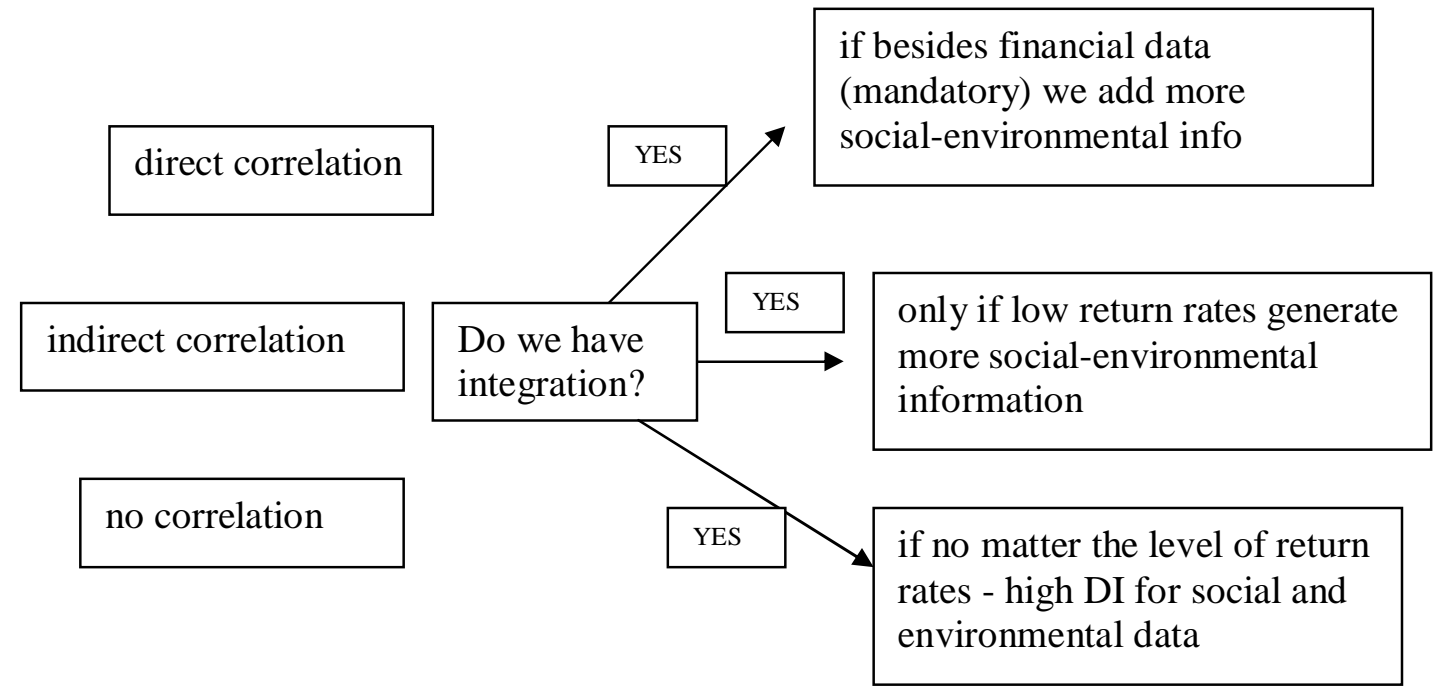

Figure no. 2. - Correlation between financial and non financial information and the integration of financial, social, and environmental information

Therefore, we identify three main stages of integration:

- high integration level

- medium integration level

- low integration level 
Table no. 4.

\begin{tabular}{|c|c|c|c|c|c|c|c|c|}
\hline Companies & ROA & & ROE & & Social DI & Check & Environmental DI & check \\
\hline $\begin{array}{c}\text { National Australia } \\
\text { Bank Limited }\end{array}$ & 0,0100 & below average & 0,1200 & Above average & 0,8646 & above average & 1,0000 & Above average \\
\hline Stockland & 0,0500 & below average & 0,0900 & Above average & 0,7500 & above average & 0,4833 & Above average \\
\hline $\begin{array}{l}\text { Diesel \& Motor } \\
\text { Engineering }\end{array}$ & 0,1000 & above average & 0,2700 & Above average & 0,9792 & above average & 0,9667 & Above average \\
\hline $\begin{array}{c}\text { Microsoft } \\
\text { Corporation } \\
\end{array}$ & 0,2100 & above average & 0,4100 & Above average & 0,5000 & above average & 0,9667 & Above average \\
\hline Clorox & 0,1300 & above average & $-1,9651$ & Below average & 0,5104 & above average & 0,4500 & Above average \\
\hline
\end{tabular}

Table no 5.

\begin{tabular}{|c|c|c|c|c|c|c|c|c|}
\hline & & & DOF & & ationiteve & & & \\
\hline Compantes & KUA & & KUE & & Social DI & Cneck & Environmental DI & check \\
\hline Vancity & 0,0100 & below average & 0,1100 & above average & 0,5833 & above average & 0,3667 & below average \\
\hline Showa Denki & 0,0180 & below average & 0,0690 & above average & 0,6531 & above average & 0,3257 & below average \\
\hline Masisa & 0,0100 & below average & 0,0300 & below average & 0,3542 & below average & 0,8000 & Above average \\
\hline
\end{tabular}

Low integrated level

\begin{tabular}{|c|c|c|c|c|c|c|c|c|}
\hline Companies & ROA & & ROE & & Social DI & Check & Environmental DI & check \\
\hline Mecu Limited & 0,0100 & below average & 0,1000 & above average & 0,0313 & below average & 0,0167 & below average \\
\hline CLP Holdings & 0,0400 & below average & 0,1150 & above average & 0,0833 & below average & 0,3333 & below average \\
\hline Tata Steel & 0,1100 & above average & 0,1900 & above average & 0,0417 & below average & 0,1333 & below average \\
\hline Takeda Pharmaceutical & 0,0900 & above average & 0,1200 & above average & 0,1354 & below average & 0,0667 & below average \\
\hline Cliffs Natural Resources & 0,1200 & above average & 0,3100 & above average & 0,0313 & below average & 0,2333 & below average \\
\hline Prudential Financial & 0,0100 & below average & 0,1000 & above average & 0,0833 & below average & 0,0000 & below average \\
\hline Coca-Cola & 0,1100 & above average & 0,2700 & above average & 0,1458 & below average & 0,2667 & below average \\
\hline
\end{tabular}


Out of 16 annual reports, 5 reports qualify for a high integration level, with all values of DI for social and environmental information above the average (Table 4). However, if we closely observe the figures from Table 4, only Diesel\&Motor Engineering have both high environmental and social disclosure $(0,97$ and 0,96$)$. Clorox company maintains its social and environmental disclosure around 0,5, while National Australia Bank Ltd also has close values for the DI. In all the other cases, the social there are discrepancies between social and environmental information disclosure. If the environmental disclosure is high, the social information is less representative, or we might witness more social disclosure and few evidence of environmental related information.

The medium integrated annual reports are the ones in which at least one of the two categories of non-financial information registers values that are above average (Table 5). Therefore, no matter the financial ratios, if the disclosure index for social/environmental information is above average, we consider that the respective report qualifies as a medium integrated one. The IAR from Vancity and Showa Denki maintain a disclosure index for social information that is above the average, while environmental disclosure is below average. For Masisa we have the opposite, because environmental DI is above average and social DI below average.

The low integrated reports are the ones that have low DI levels, no matter what the financial ratios show (Table 6). The disclosure index for social / environmental information is often close to 0 and the maximum points do not achieve a 0,4 value. Not surprisingly, the Prudential Financial Company has 0 index for environmental disclosure, being a financial institution. The maximum value for social DI $(0,1458)$ is reached by Coca Cola, while CLP Holdings registers the higher DI for environmental information $(0,3333)$.

\section{Final Remarks}

The current paper analysis the information disclosed in companies reports, in order to observe the prerequisites of integrated reporting behaviors. In the absence of a common framework, we consider the GRI G3 guidelines and use it as a reference point for the socialenvironmental information. The research studies the inclusion of environmental and social performance indicators within the reports of 16 Asian-Pacific corporations registered in the pilot program issued by the IIRC. We compute the disclosure index for the socioenvironmental information and we test the correlation with financial performance - return on assets, and return on equity. Our findings suggest the following aspects: the financial ratios generate direct/ indirect correlations, or lack of correlation with non-financial information, while the integration process is attained at high, medium, or low levels, according to the aggregation of financial, social, and environmental information.

The current research outlines the topic of integrated reporting in its earliest stage, contributing to the literature in the field of integrated reports and provides a deeper understanding of the prerequisites of GRI G3 guidelines in setting global standards for integrate reporting.

\section{References}

1. Adams, S., Simnett, R. (2011), "Integrated Reporting: An Opportunity for Australia's Not-for-Profit Sector", Australian Accounting Review 21(3), pp. 292-301.

2. Benoît, C., Niederman, G.V. (2010), "Social Sustainability Assesment Literature Review, White Paper", Measurement Science, Sustainability Consortium. 
3. Clarkson, P.M., Li, Y., Richardson, G., D., Vasvari, V.,P, (2007) "Revisiting the relation between environmental performance and environmental disclosure: An empirical analysis", Accoounting,

4. Clausen, J., Loew, T., Klaffke, K., Raupach, M., \& Schoenheit I. (2001). "The INEM Sustainability Reporting Guide -A Manual on Practical and Convincing Communication for Future-oriented Companies". Hamburg: International Network on Environmental Management (INEM).

5. Clausen, J., Loew, T., Klaffke, K., Raupach, M., Schoenheit, I. (2002) Nachhaltigkeitsberichterstattung, Erich Schmidt Verlag, Berlin.

6. Croce, M. (2011), "Does legal institutionalism rule out legal pluralism? Schmitt's institutional theory and the problem of the concrete order", Utrecht Law Review, pp. 42-59.

7. Engelinos K I, Skouloudis A, Nikolaou E I, Filho W L( 2010) “An Analysis of Corporate Social Responsibility (CSR) and Sustainability Reporting Assessment in the Greek Banking Sector", Professionals' Perspectives of Corporate Social Responsibility by Idowu S O , Filho W L Springer, 2010.

8. Godschalk, S.K.B. (2011), "An Assessment of the Relationship between Environmental and Financial Reporting by South African Listed Companies in the Mining Sector", Unpublished doctoral dissertation, University of Pretoria.

9. Hossain, M., Islam, K., Andrew, J. (2006), "Corporate Social and Environmental Disclosure in Developing Countries: Evidence from Bangladesh", Proceedings of the Asian Pacific Conference on International Accounting Issues, Hawaii.

10. Htaybat, K., (2011), Corporate online reporting in 2010: a case study in Jordan, Journal of Financial Reporting and Accounting 9(1)

11. Katelijne V.W., Wijnand B., Johanna K., Jutta K. (2011), "The state of play in sustainability reporting in the European Union", European Union's Programme for Employment and Social Solidarity .

12. Kim, K. (2003), "Stakeholder Orientation of Corporate Sustainability Evaluation Methodologies", Center for Sustainability Management (CSM).

13. Kolk, A., (2003), "Trends in sustainability reporting by the Fortune Global 250", Business Strategy and the Environment 12(5), 279-291.

14. Michael, Julia, Best Practice CS\&R Reporting in the Real Estate Industry, Global MBA Graduate, Ryerson University Toronto, 2009.

15. Michelon, G. (2007), "Sustainability Disclosure and Reputation: A Comparative Study", Paper presented at the IV Workshop on Disclosure to Financial Markets, Organizations and Society.

16. Padova, Italy.

17. Tsalavoutas, I., (2009) "The adoption of IFRS by Greek listed companies: financial statements effects, level of compliance and value relevance", The University of Edingburgh.

18. Uwuigbe, U., Uwuigbe, O., Aiayi, A.O. (2011), "Corporate Social Responsibility Disclosures by Environmentally Visible Corporations: A Study of Selected Firms in Nigeria", European Journal of Business and Management, 3(9), pp. 9-17. 